\title{
IMPERMANENCE / MUTABILITY: READING PERCY BYSSHE SHELLEY’S POETRY THROUGH BUDDHA
}

\author{
Leila Hajjari \\ Persian Gulf University \\ lhajjari@pgu.ac.ir \\ Zahra Soltani Sarvestani \\ Persian Gulf University \\ soltanizari70@gmail.com
}

Received: 22 May 2020

Accepted: 1 February 2021

\begin{abstract}
As an ongoing phenomenon, the impermanence of the world has been observed by many people, both in ancient and modern times, in the East and in the West. Two of these authors are Gautama Buddha (an ancient, eastern philosopher from the $6^{\text {th }}-5^{\text {th }}$ centuries B.C.) and Percy Bysshe Shelley (a modern Western poet: 1792-1822). The aim of this paper is to examine in the light of Buddhist philosophy what impermanence means or looks in a selection of Shelley's poems, after considering that this philosophy was not alien to the Europeans of the $18^{\text {th }}$ and $19^{\text {th }}$ centuries. Buddhism, seeing impermanence (anicca) as the foundation of the world, both acquiesces to it and urges the individuals to sway with its ebb and flow. Shelley mainly falters in the incorporation of the phenomenon into his mindset and his poems. However, he often shows a casual acceptance of it; and even, in a few cases, he presents it with a positive assessment.
\end{abstract}

Keywords: Buddhism, Shelley, impermanence, mutability, transience, anicca 


\title{
TRANSITORIEDAD / MUTABILIDAD: LECTURA DE LA POESÍA DE PERCY BYSSHE SHELLEY A TRAVÉS DE BUDA
}

\begin{abstract}
Resumen
La transitoriedad del mundo ha sido considerada un concepto relevante por muchos autores antiguos y modernos, tanto en el este como en el oeste. Dos de estos autores son Gautama Buda (ss. VI-V a.C.) y Percy Bysshe Shelley (1792-1822), el primero perteneciente a la cultura oriental antigua y el segundo a la cultura occidental moderna. El propósito de este estudio es examinar, a la luz de la filosofía budista, qué significa y cómo se manifiesta el motivo de la transitoriedad en la poesía de Shelley, partiendo del hecho de que la filosofía del budismo se difundió en la Europa de los siglos XVIII y XIX. El budismo, considerando que la "impermanencia" o transitoriedad (anicca) es una de las tres marcas de la existencia, invita al individuo a aceptar y convivir con esa inestabilidad. Por su parte, Shelley adopta normalmente una actitud dudosa respecto a la incorporación de este fenómeno en su ideario y en su poesía. Se detecta, sin embargo, que a menudo muestra una aceptación casual del concepto. En unos pocos casos, incluso presenta una visión positiva del mismo.
\end{abstract}

Palabras clave: budismo, Shelley, cambio, mutabilidad, transitoriedad, anicca 


\title{
IMPERMANENCE / MUTABILITY: READING PERCY BYSSHE SHELLEY’S POETRY THROUGH BUDDHA*
}

\author{
Leila Hajjari \\ Persian Gulf University \\ lhajjari@pgu.ac.ir \\ Zahra Soltani Sarvestani \\ Persian Gulf University \\ soltanizari70@gmail.com
}

\section{Introduction}

Why do we have many words for the quality of being short-lived? Adjectives such as impermanent, «temporary, non-permanent, [...] transient, transitory, passing, fleeting, momentary, ephemeral, fugitive, fading, short-lived, short-term, short, brief, [...] literary evanescent, fugacious» (Oxford Living Dictionaries 2018) denote a consciousness about change, deterioration, and/or destruction in all natural beings. Experienced at each single moment though not always consciously known, transience or impermanence is lived by every individual. It determines the conditions of life; in other words, life is always at the mercy of both time and change, to the extent that one may just identify life with transience/impermanence."

Impermanence is so intricately inherent in every act, in every being, in every emotion, and in every mentality that it becomes transparent and not seen any longer. Nonetheless, one knows at the back of his mind that impermanence is latent in all and every abstraction of the mind and in all and every concretization of the world. Being also a concern for scientists, transitoriness is found to be the very nature of the world since there is nothing substantial and solid in it. No single thing is what it was a moment ago because of the change in its vortex of energy; each moment we have a new world created (Dhammanada 2002: 126-129). That is probably why thinkers from the East and West, from the ancient India or Greece to the modern England, have pondered on this phenomenon. As Heraclitus states, "No man ever steps into the same river twice, for it is not the same river and he is not the same man" (Watson 2010: 303).

* The authors are grateful to the referees and editors of Littera Aperta for their critical suggestions, which have contributed to the improvement of the final version. 
Quite interestingly, philosophers from opposite sides of the globe, ancient or modern, have deeply thought about transience. Heraclitus was one among many who saw an ever-present change as the fundamental feature of the world; the idea of change: "Tempora mutantur, nos et mutamur in illis" (Times change and we change with them) (Munitz 1990: 33). This Latin sentence, inspired in Ovid and attributed to John Owen (Adeleye el al. 1999: 378), reverberates in every written work inspired by those great thinkers. Roman Stoics, as the emperor-philosopher Marcus Aurelius, considered the impermanence as a core trait of Universe (Stephens 2012: 121-124). In the later Renaissance England, people believed that, in the Great Chain of Being, anything under the moon was considered to be mutable (Hicks 1967: 12). The same concept found its way into the works of Romantic poets like Wordsworth (Hicks 1967: 14). Great Persian poets like Rumi and Umar Khayyam also observed this immanent actuality (Vaziri and Margrieter 2015), to the extent that paradoxically it has culminated in either mysticism (as in the case of Rumi) or nihilism (as in the case of Khayyam). The nihilism of Khayyam, however, has been the topic of serious debate among the Persian scholars (Aminrazavi 2008). A Japanese aesthetic world view called Wabi Sabi is also centered on the melancholic beauty of the evanescence of the cosmos (Juniper 2003: 1).

There are numerous available sources that offer interesting material for the study of impermanence. The impermanence (anicca) is one of the three marks of universe in Buddhist thought (Nyanaponika 2008). At such, it has been examined in specialized monographs (Mookerjee 1935, Stambaugh 1990), but specially in dedicated chapters, included in companions and encyclopedias on Buddhism (Laumakis 2008: 125-148, Edelglass and Garfield 2009: 26-27 and passim, Emmanuel 2013: 34-37). The reception of Buddhism in the Europe of the $19^{\text {th }}$ century has been thoroughly surveyed by Lussier (2011). Lastly, the motif of mutability in Shelley has been studied in several papers (Hick 1967, Johnson 1996, Magarian 2013, and Harding 2016).

\section{Buddhist Philosophy of Impermanence}

This ephemeral essence of existence, working in a cyclical process, rushing towards cadence is called impermanence in Buddhist philosophy. Impermanence is so deeply contemplated in Buddhism that one Buddhist thinker, Dogen, claimed that impermanence is in fact Buddhism's nature (Stambaugh 1990: 1-2). According to Buddhism, impermanence is the outcome of the cosmic law of conditionality that keeps all elements work 
harmoniously together in order to produce one phenomenon as a result (somehow like the phenomenon we know as the butterfly effect). This order enforces its might on all conditioned existence which are brought about and dependent on other processes and conditions. The law-governed universe of evanescence is nevertheless far from chaos and is morally ordered (Gowans 2003: 29). All these processes are fabricated, compounded and interdependent, which is in contrast to the unconditioned, uncompounded state of Nirvana (Gnanarama 2000: 26, Gowans 2003: 52-58, Irons 2008: 270, Runehov and Oviedo 2013: 691). This cause-and-effect order is experienced by all of the natural elements including human beings; consequently, according to the doctrine of Buddhism, three statements can be made as valid for all the animate creatures (made up of mind and matter), the first and the last of which also ascribable to the inanimate world (made up of matter only): Impermanence, Suffering or Unsatisfactoriness, and Not-self (Emmanuel 2000: 21, Irons 2008: XVI). To fully apprehend the notion of impermanence, a grasp of the two later notions is also necessary.

Impermanence denotes that all conditioned beings are in constant flux and whatever happens or is, as a matter of fact, is nothing more than fluctuating states which were conditioned by the aggregate of previous states. Nature works systematically in a way that all phenomenal existence arises because of a previous one and then give way to the following; hence, "whatever is subject to origination is subject to cessation" (Keown and Prebish 2007: 272). The speedy succession of brief states obscures a clear discernment of psychophysical states as unstable. Although impermanence applies to all conditioned things, the Enlightened One or Buddha is more concerned with the animate than the inanimate. He categorized the socalled being into five ever changing aggregates, namely, material form or body, feeling or sensation, perception, mental formations, and consciousness (Gnanarama 2000: 44). Material world pertains to the physical nature as perceived by the five senses. Feeling or sensation, originated from either mind or body, pertains to the quality we ascribe to things as pleasant, unpleasant, or neutral. Perceptions have to do with our judgements of things. Formations deal with whatever that drive us forth, things like desires and wishes. Eventually, consciousness concerns our awareness of the world and the other aggregates (Gowans 2003: 80). Presenting a simile for each aggregate, he compares

material form to a lump of foam, feeling to a bubble, perception to a mirage, mental formations to a plantain trunk (which is pithless, 
without heartwood), and consciousness to an illusion, and asks: "What essence, monks, could there be in a lump of foam, in a bubble, in a mirage, in a plantain trunk, in an illusion?

Whatever material form there be: whether past, future, or present; internal or external; gross or subtle; low or lofty; far or near; that material form the monk sees, meditates upon, examines with systematic attention, he thus seeing, meditating upon, and examining with systematic attention, would find it empty of permanent traits, he would find it insubstantial and without essence. (Gowans 2003: 26)

The five aggregates being subject to causation go through the cycle of existence. It is a cycle of production and consumption which can leave effects depending on how one deals with them (Gowans 2003: 98). In so explaining, Buddha gives way to the other two basic marks of existence, which are Unsatifactoriness and Not-self.

Lack of stability in the world brings about a feeling of un-ease to one who clings to things as if they were perpetual. No matter how much happiness a thing generates, if it is not lasting, it is not true happiness. In the entry "Anatta" (Not-self) of the Encyclopedia of Sciences and Religions, it is stated that what is impermanent might be agreeable for a time, but the ineluctable change brings about lack of satisfaction (Runehov and Oviedo 2013: 96). Whether one regards the fleetingness and yet attempts in vain to clutch fast at it or simply does not regard it, he or she is subject to suffering and dissatisfaction. Mike Siderits asserts that this suffering is an existential one; it is the frustration, the alienation and the despair one feels from the realization of one's own mortality (1946: 19). In the ultimate sense, as there is no such thing as lasting or even temporary ego-entity among the states, there is no such thing as ego or identity and thus everything is Not-self or impersonal. In other words, since all things arise from interdependently changing causes and conditions, there is no substantial existence for any object or phenomenon (Laumakis 2008: 45). The illusion of the self being shattered, the person is redeemed from serving it and providing for its behalf (Gnanarama 2013: 7). The fact that ego does not really exist unchains one from his/her painful bonds and devotions. Besides, it should be noted that Buddhism avoids the extremes of "everything is" and "everything is not" and embraces the moderate middle ground of "everything becomes" (Nyanaponika Thera 2008: 26).

In its teaching, Buddhism offers a solution to suffering caused by the transient nature of the world: knowledge of the order of cosmos is the key to 
emancipation (Burton 2004: 1). Attentive awareness of and meditation on the world as inconstant while observing its individual signs liberates one from attachment to it and nails home the idea that it cannot be the basis for a permanent happiness. This seems to imply that there is the possibility of the unchanging self in the form of happiness: though physically bound to change, the human mind/soul can be consistently in the state of happiness. But suffering is not inherent to the world: on the contrary, holding unto it, desiring it and ignoring its holy laws is what causes frustration and despair (Irons 2008: 7). The key is not to break away and become dispassionate about material forms, feelings, perception, mental formations, and consciousness; to let them fleet smoothly before and within you.

This kind of self-consciousness about the nature of the world and human experience, thus, assists mental and spiritual detachment from the material forms, and detachment brings about a liberation that is called the Great Happiness (Xing 2005: 90), the only happiness resistant to the natural order of things. This kind of Great Happiness can be achieved when one stops holding unto the world to desire anything and when one is finally able to say: "Destroyed is birth, lived is the life of purity, done is what was to be done, there is no more of this to come" (Nyanaponika Thera 2008: 7).

\section{Shelley and Buddhism}

Percy Bysshe Shelley (1792-1822) deals with the concept of mutability both in his letters to friends (Hicks 1967: 1) and in his poetry. In this paper, however, attention will be paid to a selection of his poems, leaving apart his letters for the sake of brevity and focus. The reading deploys Buddhist philosophy for the analysis of Shelley's poetry, with the aim to examine Shelley in the light of Buddhist philosophy, but not intending to trace the influence of the former on the latter. Buddhism, despite being temporally and geographically aloof from Shelley's time, is not alien to the Europeans of the $18^{\text {th }}$ and $19^{\text {th }}$ centuries (Lussier 2011).

The subjects of transience and decadence pervade Shelley's poems. Therefore, the aim should be to assess if Shelley's approach to impermanence is similar to that in Buddhism. To answer this question, one must probably also look for an answer to a broader question: did Buddhism reach Europe and more specifically England at Shelley's time to make him somehow conscious about the intricacies of the concept of impermanence? Mark Lussier's humorous way of putting it does better justice to the question: "'I wonder what's going on with Buddhism in Romantic Studies?' As it turns out, 'everything' was the answer" (Lussier 2011: xiv). Lussier 
argues that the translation of major texts generated at early Romantic age made this era the climax of Buddhist epistemology in Europe (2011: 2). He continues to say that "Buddhism emerged because Eighteenth Century's intellectual background was obsessed with the enlightenment principles that this Oriental philosophy presented" (2011: 6).

Shelley was very much aware of impermanence, but it is hard to admit that his approach to it is devotional or synchronic, as it is in Buddhism. When studying his biography, one notices that his personal life is replete with catastrophes which permanently reminded him of the transitory nature of beings: the loss of dear children caused him a real heartache. Buddha would prescribe to his pupils to shake the sorrow or angst of existence off the soul, realizing the not-self, that is "uncovered through the practice of nonattachment, establishing impermanence or emptiness as the fundamental state of all existence" (Lussier 2011: 86). This is Buddha's recommended disposition in face of impermanence: "do not weep and wail! Have I not already told you that all things that are pleasant and delightful are changeable, subject to separation and becoming other [...], all conditioned things are of a nature to decay-strive on untiringly)?" (Lussier 2011: 154). Now the question must be repeated: does Shelley in the same manner accept the calamities of life as natural? Is he able to suppress the feelings of sorrow and desperation which are usually caused by the tragic events in one's personal life, such as the loss of health or loss of two of his children in one year?

Shelley's observation of the ephemeral nature of all things and beings on the world is manifest in most of his poems in which something is fled, decayed, dead, gone, faded, changed, departed, or lost. He observes the very evanescent nature of every natural being. The influence on his poetry from varied philosophical resources added to the deepness of his approach. To assess Shelley's varied inceptions of the concept of impermanence, poems such as "Hymn to Intellectual Beauty", "Ode to the West Wind", "Mont Blanc", "Time Long Past", "Ozymandias", "A Lament", "The Past" and "To-oh-there are spirits of the air" along with the two "Mutability" poems, one written in 1816 and the other in 1824, have been analyzed.

\section{Transience in Shelley's poetry}

In "Hymn to Intellectual Beauty" (1817), the speaker addresses and worships the Spirit of Intellectual Beauty which invisibly touches upon but stands apart from the physical world and human's heart. This spirit of 
Intellectual Beauty is an inconstant visitor that brings vanishing moments of inspiration. This inconstancy is represented by similes of natural beauty:

Like hues and harmonies of evening,

Like clouds in starlight widely spread,

Like memory of music fled,

Like aught that for its grace may be

Dear, and yet dearer for its mystery. (11. 8-12 in Shelley 2000: 73)

Having touched upon human thought and form, the spirit is gone and what is left is a vacant, desolate state. By the passing away of the spirit, the speaker is left reflecting on the reason for this departure and on transience. In response to his own question, the poet yet asks more questions of the same nature:

Ask why the sunlight not for ever

Weaves rainbows o'er yon mountain-river,

Why aught should fail and fade that once is shown,

Why fear and dream and death and birth

Cast on the daylight of this earth

Such gloom, why man has such a scope

For love and hate, despondency and hope? (11. 18-24 in Shelley

2000: 73)

The poetic persona maintains that these questions have not ever answered, and that doubt, chance, and mutability are overcast in all we hear and all we see. If the Intellectual Beauty lingered firmly in human heart, he believes, he would be immortal and omnipotent and would escape the dark reality of decadence. Associating the spirit with all the goodness left for humanity, the speaker implores it to stay. Another manifestation of mutability of the natural world is given in the last stanza, in which things change in a way that their previous state is faded from the memory.

The poet is contemplating the transitoriness and vagueness of the natural sublime that once visited him as a child. He still sees and praises the traces of this sublimity in the five aggregates of material forms, sensation, perception, mental formations and consciousness. Aiming at the law of impermanence, he questions its essence and laments why it must be so. However, because of the beauty he sees therein, he cannot willingly relinquish the five aggregates, so this attachment leaves him disconsolate. 
In "Ode to the West Wind" (1820), the speaker addresses the West Wind, which is associated with moving onwards, revolution, and causing change in the world. The change that the West Wind brings about is not only of decay and withering but also, by spreading seeds, of growth. The speaker admires the wind for its wildness, uncontrollability, freedom, and its dual might for destruction and regeneration. The West Wind is the harbinger of change, as his sister, the spring wind, is a factor of birth and youth. They are described as two complementary forces which engender the cyclical transformation of the world:

O wild West Wind, thou breath of Autumn's being,

Thou, from whose unseen presence the leaves dead

Are driven, like ghosts from an enchanter fleeing, [...]

Each like a corpse within its grave, until

Thine azure sister of the Spring shall blow

Her clarion o'er the dreaming earth, and fill

(Driving sweet buds like flocks to feed in air)

With living hues and odours plain and hill (1l. 1-3, 8-12 in Shelley 1872:

3)

The poetic persona, believing that both winds are swift, proud, and untamable, and he is subject to time and to the thorns of life, wishes to be empowered with the West Wind. He wants his thoughts and words, that will rejuvenate and cause change, to be carried across the world (Kapstein 1936: 1070). He wants the wind to prophecy that resurrection of nature, or, taken metaphorically, of the thoughts of people, is upcoming: "If Winter comes, can Spring be far behind?" (1. 70, in Shelley 1872: 5). In this ode, unlike the previous one, the cyclical process of change is praised and embraced. Far from his usual melancholic feeling about change, Shelley is now seeing through the cycle and observing the whole interconnected rejuvenating system, disentangling himself from the desire for stasis and thus a step closer to the belief that characterizes Buddhism. He is reassuring himself that change does not mean extinction, since regeneration follows destruction (Hicks 1967: 5).

In his ode "Mont Blanc: Lines Written in the Vale of Chamouni" (1817), the mountain is characterized by the restless movement, turbulence and contending forces embodied in the images of water, fast flowing rivers, stormy seas, and whirlpools (Harding 2016: 623). Mont Blanc and nature are a mysterious and powerful force that interacts with the observer's mind; 
he regards the natural sublimity of the landscape as the evidence of a systematic natural process (Duffy 2005: 9). Listening to the mysterious voice of the wilderness, one who is wise, great, and good can interpret that destruction and creation of the nature are representative of the mighty rule of impermanence. Endurance of this power that governs the fleeting nature of all beings is presented in the fourth stanza:

The works and ways of man, their death and birth,

And that of him and all that his may be;

All things that move and breathe with toil and sound

Are born and die; revolve, subside, and swell.

Power dwells apart in its tranquility,

Remote, serene, and inaccessible. (11. 91-96 in Shelley 2000: 85)

Contemplating the nature of mind, of knowledge, of reality, and of the relation of human mind to universe, Shelley manifests contradictory response to the "works and ways of man" (1.91), simultaneously accepting and rejecting man's ability to reach tranquility; he first implies a disbelief in the substantial existence of the material universe by asserting his freedom of mind and active creation of its knowledge, but, at the same time, he admits that his thought is governed by "the secret Strength of things" (1. 139) which is the mighty rule of impermanence. Up to nearly the end of the poem, his attitude is of awe and praise of the remote amoral power of Necessity, eternally ruling the impermanent universe of the five aggregates symbolized by the river Arve. However, in the last three lines, an explicit reluctance to accept this rule is manifested by his change of attitude from worship to defiance, bringing his poem into an anti-climax (Kapstein 1947: 10461048).

Shelley longs for the things that have vanished long ago, yet he knows he cannot recover them. He feels melancholic for having forever lost the sweetness, and disappointed for not having seized it. This vision of unalterable and inevitable fugitiveness of life is portrayed in the last part of "Time Long Past" (1870):

'Tis like a child's belovèd corpse

A father watches, till at last

Beauty is like remembrance, cast

From Time long past. (Shelley 1872: 96, 11. 15-18) 
The tone, the hope, the love, and the sweet dream now long past do only induce pain, due to miscomprehension of their fleeting nature, whereas what we expect from a poet who holds unto the Buddhist doctrine is to forget, without any kind of devotion to the self or entanglement in the dolorous and melancholic status.

The sonnet "Ozymandias" (1818) deals with the notion of decadence and transience of human endeavor. The lyric speaker recounts what a traveler observed in an antique land. He saw the remnants of the statue of Ramses II, famous for erecting magnificent constructions. The "sneer of cold command" (1. 5 in Shelley 1872: 25) and pride detected in the eroded visage of the sculpture, as well as the self-conceited words that appear on the pedestal, are mocked with irony. Emphasizing the desolation of the surrounding area with alliteration, 'boundless and bare, / the lone and level sands stretch far away" (11. 13-14 in Shelley 1872: 26), the poet creates a contrast with the boast of the king, who claims to have erected an enduring work. The devastating power of nature and time deconstructs the king's statement, by destroying the splendor that he vaunted about.

It is true that the speaker of this poem is neither melancholic nor indignant about decadence (an effect of impermanence). Mocking the vanity of the petty mankind, he regards the decadence as the natural humbling force of the universe, in a way that no human grandeur is capable to withstand it. History is a testimony to the feebleness of any kind of force against the basic order. Civilizations and kingdoms spring, flourish, and fade away as if none ever existed.

In two short stanzas of "A Lament", the poetic persona of the poem wistfully grieves for his inability to grab and, when lost, recreate the prime of life, world, and time. The mutability of his state is evident in the third line: "Trembling at that where I had stood before" (1. 3). He has reluctantly accepted that the vanished glory of his early days will never again be relived and the refrain "No more -Oh, never more!" (1l. 5 and 10 in Shelley 1872: 101) enforces the implication of regret and nostalgia. The disinclination to acquiesce to the fugitiveness of life renders the speaker doleful again.

"The Past" is a poem that revolves around the evanescence of joy and how woe begotten one embraces bygone time. Although the sweetness of the idealized past has faded away, it is cherished in the memory like blossoms that once existed, fruited, and then withered, as well as the leaves of hope which are yet to blossom. Anything dead should get corrupted and be moldering, but an exception to this rule is gaiety of the days past, held 
dear in memory. Even if attempted to forget, one will not be triumphant, because there are reminiscences of the apparitional past that haunt the mind, as shown in the poem by a metaphor: "Forget the dead, the past? Oh, yet / There are ghosts that may take revenge for it" (11. 7-8 in Shelley 1846: 186). The memories of the lost joys and the accompanying regrets unpleasantly heaped up in the heart and soul will cause agony. As the poet writes: "joy, once lost, is pain" (1. 12 in Shelley 1846: 186).

Something that is very significant in "To-oh-there are spirits of the air" is the presence of a distinct self for whose sake the persona is struggling and demands the emotional accompaniment of others. Let down by the exterior provisions for the self, he eventually moans of their insubstantiality, "Ah! Wherefore didst thou build thine hope / On the false earth's inconstancy?" (11. 19-20 ; Shelley 1846: 66). Criticizing himself for trusting others' wiles, he retreats to his own soul. By mistreatment, the soul has turned unpleasantly fiendish albeit still artless and sincere. He prohibits himself from chasing the demands of this soul, fearing that it may bring him more pain. At last, he decides not to ruffle the stasis of his predetermined dark fate. Throughout the poem, it seems that Shelley acknowledges the asserted edges for impermanence in Buddhism: "Whatever is stored up is bound to run out. Whatever rises up is bound to fall down. Whatever comes together is bound to fall apart. Whatever is born is impermanent and is bound to die" (Rinpoche and Lama 1998: 46). Despite Shelley's profound observance of the mutable world inside and outside him, he is not able to liberate himself from the pangs that he has so far suffered pursuing for the sake of self. He lacks the true insight to keep his satisfaction beyond the alternating ups and downs of the world.

The two Mutability poems represent the poet's conflicting perspectives. The problematic areas causing this conflict are necessity, free will, reason, perception, and perfection (Hicks 1967: 3). In his pictorial lyric poem, "Mutability" (1816), which is exclusively dedicated to the theme of our concern, Shelley employs similes to represent the inconstancy of all dimensions of human life, or, to put it in the Buddhist terminology, the five aggregates. In the first quatrain, the night is taken as a metaphor for death, and the moon then is a symbol of permanence, which constitutes a contrast to the passing clouds which resemble humanity in their fleetingness. Restlessly speeding toward their death, their natural delight inevitably vanishes in the darkness of the night or death (West 2007: 51).

Another simile is created in the second stanza, this time between a lyre with dissonant strings that are played by every passing wind gust and the 
lives that are susceptible to transform with the change of circumstances. Both eventually will drown in Lethe.

In the third stanza, rest and wakefulness are declared to be inconsistent in that there is always something to interrupt their course, being a disturbing dream or a digressive thought. The change is not essentially good or bad as expressed in this section, and the aggregates of sensation, perception, mental formations and consciousness are added to the previously appeared material forms.

The poem closes by the casual assertion that we have no control over joy or sorrow or other emotional states we choose to have, because they are consigned to the law of mutability that constrict us; thus, change is relative to matter, to systems of thought, and to emotion (Hicks 1967: 3):

It is the same!-For, be it joy or sorrow,

The path of its departure still is free;

Man's yesterday may ne'er be like his morrow;

Nought may endure but Mutability (11. 13-16 in Shelley 1864: 61)

The one and only deviator from the flow of constant change is mutability itself. The Enlightened One also believed that the only constant features of the world are the laws that govern it, impermanence being one among them (Gowans 2003: 35).

"Mutability" is the ultimate epitome of how Shelley regarded mutability and how he accepted this ever-pervasive regularity. It gives the exact same picture that the doctrine of impermanence offers, while lacking its amendments of suffering. Since asserted in a casual way, there is no clue for attachment and its ensuing pain; yet there is no mindfulness of it, either. On the other hand, the third sign of existence, impersonality, seems partially to veil itself in the adjective "we" and the ever-present manifestations of impermanence.

The second Mutability poem is also entitled "The Flower That Smiles Today" (1824). The text asserts that "nothing gold can stay", as in the famous poem by Robert Frost (1964: 272), so it urges to enjoy the sparkle before it switches place with darkness. The analogy of the flower conveys the beauty that Shelley sees in its short-term life; and the lightening too reveals his admiration for its bright and beautiful defiance against the empty night. Besides this admiration, a gloomy tone can also be detected.

Even the most precious bestowals of life, which are virtue, friendship, and love, ultimately submit to the mighty rule of transience. The joys and 
the so-called possessions in our lives pass and perish; we proceed through dream-like life, while the "skies are blue and bright" (1. 15 in Shelley 1864: 258), "flowers are gay" (1. 16) and "yet the calm hours creep" (1. 19). So, the poem invites the readers to seize the day and to enjoy the dream, because we are destined to futilely "wake to weep" (1.21). The reactions to the motivating result of necessity and show the inability to deal with the complex forces of life as well as with one's intense desires (Hicks 1967: 5).

The temptation for desirable things mentioned in the first stanza is the vacuous promise of a world with a fleeting nature which only leaves one with agony of its loss. The mention of our survival in "all which ours we call" (1. 14 in Shelley 1864: 258) implies that they are not really for us to claim possession. The rationalization that, since they are ephemeral, they cannot be called property, can be seen as partially compatible with the third Buddhist sign: according to this, since all phenomena are in a state of flux, they are empty of any intrinsic self. This notion can be applied to both the things we consider as ours and what we call as self.

\section{Conclusions}

Percy Shelley carefully observed the phenomenon of impermanence in all aspects of human life and nature, but acquiesced conflictingly to the might with defiance, dislike, and melancholy. In some cases, he reacted with casual acceptance or praise. Buddhism takes impermanence as the basic sign of the universe, which entails suffering and propagates impersonality. Deep insight into the phenomena, Buddha believed that impermanence helps us to appreciate the intensity of our experiences (without painfully clinging to them) and to welcome the ensuing. Thus, it is feasible to gain a total liberation from suffering and achieve Nirvana (the Great Happiness). The rise and fall, the gain and loss, and the creation and extinction, incessantly happening about and within us, are inevitable: therefore, the only escape from this fickleness is its acceptance. The successive waves of life need be surfed on, unless one is drowned deep with the first fall. The recommended approach to this system is not to avoid it but to accept and incorporate it. Transience can also be relieving at the time of despair for its promise of an ensuing rise. With this regard, Buddhism is neither pessimistic nor optimistic but realistic, whereas Shelley, under the sway of the very natural law, fluctuates between pessimism and realism, even though in few cases such as "Ode to the West Wind" a kind of optimistic glorification is present. Why is he different in his approach to 
impermanence in comparison to Buddhism, despite the possible familiarity to and influence from Buddhism, must be the subject for another study. 


\section{Works Cited}

Adeleye, Gabriel G. et al. (1999). World Dictionary of Foreign Expressions. A Resource for Readers and Writers. Wauconda, Ill.: Bolchazy-Carducci Publishers.

Aminrazavi, Mehdi (2005). The Wine of Wisdom: The Life, Poetry and Philosophy of Omar Khayyam. Oxford: Oneworld Publications.

Burton, David (2004). Buddhism, Knowledge and Liberation. A Philosophical Study. Burlington, Vermont: Ashgate Publishing.

Dhammanada, Sri (2002). What Buddhist Believe. Expanded edition. Malaysia: Buddhist Missionary Society.

Duffy, Cian (2005). Shelley and the Revolutionary Sublime. Cambridge: Cambridge UP.

Edelglass, William, and Jay L. Garfield (2009). Buddhist Philosophy: Essential Readings. Oxford: Oxford UP.

Emmanuel, Stephen M. A. (2013). Companion to Buddhist Philosophy. West Sussex: Wiley-Blackwell.

Frost, Robert (1964). Complete Poems of Robert Frost. Seventeenth Printing. New York: Holt, Rinehart and Winston.

Gnanarama, Pategama (2000). Essentials of Buddhism. Singapore: Pali College of Singapore.

Gowans, Christopher W. (2003). Philosophy of the Buddha. New York: Routledge.

Harding, Anthony John (2016). "Signs of Change. Percy Shelley's Language of Mutability as Precursor to Darwin's Theory of Evolution." Literature Compass 13.10: 617-627.

Hicks, Wreathea G. (1967). Shelley's Changing Concept of Mutability. MA Thesis. Kansas: The Kansas State Teachers College of Emporia.

Irons, Edward (ed.) (2008). Encyclopedia of Buddhism. New York: Facts on File.

Johnson, Lee (1996). "Shelley's Music of Mutability," Graven Images: A Journal of Culture, Law, and the Sacred. Madness, Melancholy, and the Limits of the Self 3: 114-121.

Juniper, Andrew (2003). Wabi Sabi: The Japanese Art of Impermanence. New York: Schocken Books.

Kapstein, I. J. (1936). "The Symbolism of the Wind and the Leaves in Shelley's «Ode to the West Wind»". PMLA 51.4: 1069-1079.

Kapstein, I. J. (1947). “The Meaning of Shelley's «Mont Blanc»”. PMLA 62.4: 1046-1060. 
Keown, Damien, and Charles S. Prebish (2007). Encyclopedia of Buddhism. London: Routledge.

Laumakis, Stephen J. (2008). An Introduction to Buddhist Philosophy, Cambridge: Cambridge University Press.

Lussier, Mark (2011). Romantic Dharma. The Emergence of Buddhism into Nineteenth-Century Europe. New York: Palgrave Macmillan.

Magarian, Barry (2013). "Shelley's Alastor. the Mutability of Identity." The Keats-Shelley Review 12.1: 77-103.

Mookerjee, Satkari (1935). The Buddhist Philosophy of Universal Flux. Calcutta: University of Calcutta Press.

Munitz, Milton K. (1990). Cosmic Understanding. Philosophy and Science of the Universe. Princeton: Princeton UP.

Nyanaponika Thera (ed.) (2008). The Three Basic Facts of Existence I: Impermanence (Anicca). Collected Essays with a Preface by Nyanaponika Thera. The Wheel Publication No. 186/187. Kandy, Sri Lanka: Buddhist Publication Society.

Oxford Living Dictionaries (2018). Oxford: Oxford University Press. https://en.oxforddictionaries.com

Rinpoche, Patrul, and Dalai Lama (1998). The Words of My Perfect Teacher. A Complete Translation of a Classic Introduction to Tibetan Buddhism. Boston: Shambala.

Runehov, Anne L. C. and Lluis Oviedo (eds.) (2013). Encyclopedia of Sciences and Religions (2013). New York and London: Springer.

Shelley, Percy Bysshe (1846). The Minor Poems of Percy Bysshe Shelley. Princeton: Princeton University.

Shelley, Percy Bysshe (1872). A Selection from the Poems of Percy Bysshe Shelley. Edited by Mathilde Blind. Leipzig: Bernard Tauchnitz.

Shelley, Percy Bysshe (2000). The Complete Poetry of Percy Bysshe Shelley. Vol. 1. Edited by Donald H. Reiman and Neil Fraistat. Baltimore: Johns Hopkins UP.

Siderits, Mark (1946). Buddhism as Philosophy. An Introduction. Aldershot: Ashgate Publishing Limited.

Stambaugh, Joan (1990). Impermanence Is Buddha-nature. Dōgen's Understanding of Temporality. Honolulu: University of Hawaii.

Stephens, William O (2012). Marcus Aurelius: A Guide for the Perplexed. London and New York: Continuum International Publishing Group. Vaziri, Mostafa, and Reihard Margrieter (2015). Rumi and Shams' Silent Rebellion. Parallels with Vedanta, Buddhism, and Shaivism. London: Palgrave Macmillan. 
Watson, Richard (2010). Future Files. A Brief History of the Next 50 Years. Toronto: Nicholas Brealey Publishing.

West, Sally (2007). Coleridge and Shelley. Textual Engagement. Hampshire: Ashgate.

Xing, Guang (2005). The Concept of the Buddha. Its Evolution from Early Buddhism to the Trikāya Theory. London: Routledge Curzon. 
